\title{
ReSEARChArticle
}

\section{A biocontrol of stored product pest Corcyra cephalonica (Lepidoptera:Pyralidae) by secondary metabolite of Beauveria bassiana (Balsamo) Vuillemin (Lepidoptera: Pyralidae)}

\author{
S. GOWRILAKSHMI, M.S. NALINASUDARI, N. DEEPA AND ARUMUGHAM
}

\begin{abstract}
SUMMARY
Entomopathogenic fungus belong to the fungal group which are widely used in the integrated pest management systems. These fungi are insect associated and kills the agricultural pests. So they are used as biopesticides and by replacing the chemical pesticides and do save the human beings and environment from hazardous chemical pollution. These entomopathogenic fungus produce many secondary metabolites which have antimicrobial activities.It also has bioactive compounds that contains larvicidal and insecticidal activities. Corcyra cephalonica, a stored product pest is a major agricultural pest which causes economic loss to our country. Though there may be evidences for the conidial and spore treatments but secondary metabolite usages were very less. So the present study was undertaken to check the secondary metabolite of entomopathogenic fungi Beauveria bassiana an effective agent to control the stored product pest corcyra cephalonica and can be used in integrated pest management systems.
\end{abstract}

Key Words : Entomopathogenic fungus, Corcyra cephalonica, Insecticide, IPM

How to cite this article : Gowrilakshmi, S., Nalina Sudari, M.S., Deepa, N. and Arumugham (2016). A biocontrol of stored product pest Corcyra cephalonica (Lepidoptera:Pyralidae) by secondary metabolite of Beauveria bassiana (Balsamo) Vuillemin (Lepidoptera: Pyralidae). Internat. J. Plant Sci., 11 (2): 156-160, DOI: 10.15740/HAS/IJPS/11.2/156-160.

Article chronicle : Received : 22.01.2016; Revised : 02.04.2016; Accepted : 16.05.2016 